\title{
Hubungan Dukungan Keluarga Dengan Derajat Hipertensi Pada Pasien Hipertensi Di Gampong Meunasah Tambo Kecamatan Peudada Kabupaten Bireuen
}

\author{
Fonna Asyura $^{1}$, Sri Andala ${ }^{2}$, Fadhila $^{3}$
}

${ }^{1}$ Mahasiswa STIKes Muhammdiyah Lhokseumawe
2Dosen Prodi Ilmu Keperawatan STIKes Muhammadiyah
${ }^{3}$ Dosen Prodi Ilmu Keperawatan STIKes Muhammadiyah
Correspondence : fonnaasyura06@ gmail.com

\begin{abstract}
Hypertension is a hemodynamic disorder or imbalance that occurs, causing blood pressure (systole and diastole) to increase beyond normal limits (> 130/80 mmHg). Hypertension does not always show accurate symptoms so that many people do not realize that they have high blood pressure. The impact of organ damage due to hypertension depends on the degree of hypertension. This requires serious attention for every individual and family in the management of good health. This study aims to determine the relationship between family support and the stage of hypertension in hypertensive patients. This study used a correlational design with a cross sectional approach. The population was 40 people and the sample was taken by total sampling. Data collection was carried out from 15 to 25 July 2020 by measuring blood pressure and interviewing a questionnaire. The collected data were processed using a computer program to be analyzed using the chi square test with a significance level of $\alpha=0,05$. The results showed that there was a significant relationship between informational support $(\mathrm{P}=0.001)$, reward support $(P=0.003)$, instrumental support $(P=0.002)$, emotional support $(P=0.013)$, and family support $(\mathrm{P}=0.000)$ with stage of hypertension. It can be concluded that the better family support, the better the stage of hypertension in people with hypertension. The results of this study are expected for future researchers to conduct better further research and follow the development of advanced science so that perfect results are obtained regarding the relationship of family support with the stage of hypertension in hypertensive patients.
\end{abstract}

\section{Keywords $\quad$ : Family Support, Hypertension of stage.}

\begin{abstract}
ABSTRAK
Hipertensi adalah kelainan atau ketidakseimbangan hemodinamik yang terjadi sehingga menyebabkan tekanan darah (sistol dan diastol) meningkat melebihi batas normal (> 130/80 mmHg). Hipertensi tidak selalu menunjukkan gejala yang akurat sehingga banyak orang yang tidak menyadari bahwa dirinya memiliki tekanan darah tinggi. Dampak kerusakan organ akibat hipertensi bergantung pada derajat hipertensi. Hal ini membutuhkan perhatian yang serius bagi setiap individu dan keluarga dalam pengelolaan kesehatan yang baik. Penelitian ini bertujuan untuk mengetahui hubungan dukungan keluarga dengan derajat hipertensi pada pasien hipertensi. Penelitian ini menggunakan desain korelasional dengan pendekatan cross sectional. Populasi sebanyak 40 orang dan pengambilan sampel dengan cara total sampling. Pengumpulan data dilakukan pada tanggal $15 \mathrm{~s} / \mathrm{d} 25$ Juli 2020 dengan mengukur tekanan darah dan wawancara kuesioner. Data yang terkumpul diolah dengan menggunakan program komputer untuk dianalisis menggunakan uji chi square dengan tingkat kemaknaan $\alpha=0,05$. Hasil penelitian menunjukkan bahwa terdapat hubungan yang signifikan antara dukungan informasional $(P=0,001)$, dukungan penghargaan $(P=0,003)$, dukungan instrumental $(P=0,002)$, dukungan emosional $(P=0,013)$, dan dukungan keluarga $(P=0,000)$ dengan derajat hipertensi. Dapat disimpulkan bahwa semakin baik dukungan keluarga maka akan semakin baik derajat hipertensi pada penderita hipertensi. Hasil penelitian ini diharapkan bagi peneliti selanjutnya untuk melakukan penelitian lanjut yang lebih baik dan mengikuti perkembangan ilmu pengetahuan yang maju sehinggadiperoleh hasil yang sempurna tentang hubungan dukungan keluarga dengan derajat hipertensi pada pasien hipertensi.
\end{abstract}

Kata kunci

: Dukungan Keluarga, Derajat Hipertensi. 


\section{PENDAHULUAN}

Dalam kehidupan dunia yang sudah serba modern seperti saat ini, penyakit jantung dan pembuluh darah (kardiovaskuler) menjadi masalah kesehatan utama di negara maju maupun negara berkembang. Hipertensi menjadi penyebab kematian nomor satu di dunia setiap tahunnya. Hipertensi termasuk salah satu penyakit kardiovaskular yang paling umum dan paling banyak disandang oleh masyarakat (Kemenkes, 2019).

Hipertensi merupakan keadaan seseorang dimana tekanan darah sistoliknya $\geq 140$ $\mathrm{mmHg}$ dan tekanan diastoliknya $\geq 90 \mathrm{mmHg}$, pada pemeriksaan yang berulang. Tekanan sistolik merupakan pengaruh utama yang menjadi dasar penegakan diagnosis hipertensi (Perki, 2015). Tekanan darah sistolik adalah tekanan yang timbul ketika jantung berkontraksi, sedangkan tekanan darah diastolik adalah tekanan yang ditimbulkan ketika jantung relaksasi (Asfuah, 2012). Data World Health Organization (WHO) tahun 2015 menunjukkan sekitar 1,13 Miliar orang di dunia menyandang hipertensi, artinya 1 dari 3 orang di dunia terdiagnosis hipertensi. Jumlah penyandang hipertensi terus meningkat setiap tahunnya, diperkirakan pada tahun 2025 akan ada 1,5 Miliar orang yang terkena hipertensi, dan diperkirakan setiap tahunnya 9,4 juta orang meninggal akibat hipertensi dan komplikasinya (Kemenkes, 2019).

Di Indonesia prevalensi hipertensi tahun 2018 berdasarkan hasil pengukuran pada penduduk usia $\geq 18$ tahun tercatat sebesar $26,45 \%$ atau naik $16,75 \%$ dibandingkan pada 2013 hanya $9,7 \%$, prevalensi tertinggi berada di Kalimantan Selatan (44.1\%) dan terendah di Papua $(22,2 \%)$. Hipertensi terjadi pada kelompok umur 31-44 tahun $(31,6 \%)$, umur 45-54 tahun (45,3\%), umur 55-64 tahun $(55,2 \%)$ (Riskesdas, 2018).

Di Aceh sendiri prevalensi hipertensi tahun 2018 berdasarkan hasil pengukuran pada penduduk usia $\geq 18$ tahun tercatat sebesar $34,1 \%$ naik $16,75 \%$ dibandingkan pada 2013 hanya $9,7 \%$ yang terdiagnosis. Sementara untuk Kabupaten dan kota juga menunjukkan angka yang hampir berimbang diantaranya di Kabupaten Aceh Utara ada 21,08\% kasus, di Kota Lhokseumawe 27,43\% kasus serta di kabupaten Bireuen 27,15\% kasus (Riskesdas, 2018).

Hipertensi merupakan salah satu penyakit yang termasuk dalam sepuluh penyakit terbanyak di puskesmas-puskesmas yang ada di provinsi Aceh. Tahun 2013 hipertensi berada pada peringkat pertama terbanyak kasus penyakit tidak menular di provinsi Aceh dengan jumlah kasus 116.206 kasus, kemudian pada tahun 2014 kasus hipertensi di provinsi Aceh meningkat hampir dua kali lipat dari tahun 2013 yaitu sebanyak 350.946 kasus (Dinkes Aceh, 2015).

Berdasarkan data dari dinas kesehatan Bireuen, hipertensi menduduki peringkat nomor satu prevalensi penyakit tidak menular paling tinggi dengan jumlah kasus 3.445, diikuti dengan diabetes melitus tipe 2 (2.131 kasus) dan rhematoid artritis (1.842 kasus). Meski angka kejadian penyakit tidak menular lebih rendah dari pada penyakit menular (influenza saja 6.354 kasus) penyakit tidak menular patut lebih diperhitungkan karena kemungkinan komplikasi yang dapat ditimbulkan lebih besar (Dinkes Bireuen, 2019).

Untuk itu dibutuhkan perhatian yang serius bagi setiap individu maupun keluarga dengan tekanan darah tinggi agar progresivitas hipertensi dapat diturunkan. Ada beberapa faktor yang saling berhubungan yang dapat ditingkatkan efisiensinya supaya hipertensi dapat dikendalikan, seperti social support, environmental factors, dan familiy support. Familiy Support (dukungan keluarga) berpengaruh positif dalam mengontrol segala penyakit. Dukungan keluarga dapat dipahami sebagai bantuan dan perlindungan yang diberikan kepada seseorang, dukungan keluarga telah terbukti secara positif dengan hasil kesehatan untuk berbagai kondisi medis, termasuk pasien yang dalam perawatan rawat inap di rumah sakit (Jakub, 2017).

Dukungan keluarga akan membantu meningkatkan pengetahuan tentang hipertensi dan memberikan motivasi pada pasien. Pasien yang memiliki dukungan dari keluarga mereka menunjukkan perbaikan perawatan dari pada yang tidak mendapat dukungan dari keluarga. Dukungan keluarga dapat berupa informasi mengenai penyakit mereka atau mengingatkan untuk minum obat (Flynn et al, 2013). 
Dukungan keluarga juga dikaitkan dengan perbaikan tekanan darah pada keluarga yang sakit berupa dukungan emosional, dukungan penghargaan, dukungan instrumenal, dan dukungan informasional (Friedman et al., 2014). Secara spesifik, dengan adanya dukungan keluarga yang adekuat terbukti berhubungan dengan menurunnya mortalitas (Fajriyah et al., 2016).

Dari penelitian sebelumnya yang dilakukan oleh Isra, dkk (2017) tentang hubungan dukungan keluarga dengan derajat hipertensi pada pasien hipertensi di Puskesmas Ranomuut Kota Manado didapatkan bahwa ada hubungan yang signifikan antara dukungan keluarga dengan derajat hipertensi seperti motivasi, self-care dan lain sebagainya $(p=0,000)$.

Hal ini juga sejalan dengan penelitian Efendi \& Larasati (2016) tentang dukungan keluarga dalam manajemen penyakit hipertensi berhasil menyimpulkan bahwa pengaruh keluarga dalam peran sebagai fungsi kesehatan dapat terangkum dalam subkategori support system utama keluarga, keseimbangan finansial, kontrol kesehatan, dan wellbeing.

Penelitian Bisnu (2017), tentang hubungan dukungan keluarga dengan derajat hipertensi pada pasien hipertensi di puskesmas Ranomuut kota Manado melalui uji spearman juga didapatkan bahwa jumlah responden yang memiliki dukungan keluarga tinggi sebanyak 39 responden $(57,4 \%)$, dan yang berada pada klasifikasi pre hipertensi sebanyak 37 responden $(54,4 \%)$ dan yang berada pada klasifikasi hipertensi sebanyak 31 responden $(45,6 \%)$, sehingga dapat disimpulkan bahwa ada hubungan dukungan keluarga dengan derajat hipertensi $(\mathrm{p}$ value $=$ 0,000 ).

Dan juga berdasarkan penelitian yang pernah dilakukan oleh Almina dkk (2018) tentang pengaruh pengetahuan, sikap, dan dukungan keluarga terhadap diet hipertensi juga berhasil menyimpulkan ada pengaruh yang signifikan antara pengetahuan, sikap, serta dukungan keluarga terhadap pelaksanaan diet hipertensi yang dilihat dari nilai signifikan $(\mathrm{p}=0,001)$.

Berdasarkan survey awal di Gampong Meunasah Tambo bulan Mei 2020 pada10 keluarga, yang salah satu bahkan ada dua anggota keluarganya yang mengalami darah tinggi (TD $\geq 130 / 90 \mathrm{mmHg}$ ). Dari hasil wawancara terdapat 7 keluarga yang anggota keluarganya mengalami hipertensi mendapat dukungan dari keluarganya untuk cepat sembuh dan sering mengingatkan untuk selalu mengontrol tekanan darahnya secara rutin ke puskesmas atau ke layanan kesehatan lainnya. Sedangkan 3 anggota keluarga lainnya yang mengalami hipertensi tidak mendapat dukungan dari keluarganya dan tidak pernah rutin mengontrol tekanan darahnya ke puskesmas atau layanan kesehatan lainnya.

Berdasarkan data dan fakta penelitian tersebut diatas, peneliti ingin membuktikan secara ilmiah tentang hubungan dukungan keluarga dengan derajat hipertensi pada pasien hipertensi di Gampong Meunasah Tambo Kecamatan Peudada Kabupaten Bireuen Tahun 2020.

\section{METODE PENELITIAN}

Desain penelitian yang digunakan adalah korelasional dengan jenis rancangan cross sectional. Penelitian dilakukan di Gampong Meunasah Tambo Kecamatan Peudada Kabupaten Bireuen. Populasi dalam penelitian ini adalah seluruh penderita hipertensi yang ada di Gampong Meunasah Tambo Kecamatan Peudada Kabupaten Bireuen yang berjumlah 40 orang. Pengambilan sampel dilakukan secara total sampling sebanyak 40 responden. Analisa data dilakukan secara univariat dan bivariat menggunakan rumus Uji Chi Square.

\section{HASIL PENELITIAN}

Penelitian ini dilaksanakan di Gampong Meunasah Tambo Kecamatan Peudada Kabupaten Bireuen pada tanggal 15 s/d 25 Juli 2020.

Tabel 1 Data Demografi Distribusi Frekuensi Responden

\begin{tabular}{cccc}
\hline No. & Usia (tahun) & F & \% \\
\hline 1 & $26-35$ & 9 & 22,5 \\
2 & $36-45$ & 15 & 37,5 \\
3 & $46-55$ & 15 & 37,5 \\
4 & $56-65$ & 1 & 2,5 \\
\hline & Jumlah & $\mathbf{4 0}$ & $\mathbf{1 0 0}$ \\
\hline
\end{tabular}




\begin{tabular}{|c|c|c|c|}
\hline No. & Jenis Kelamin & $\mathbf{F}$ & $\%$ \\
\hline & Laki-laki & 19 & 47,5 \\
\hline \multirow{2}{*}{$\begin{array}{l}1 \\
2\end{array}$} & Perempuan & 21 & 52,5 \\
\hline & Jumlah & 40 & 100 \\
\hline No. & Pendidikan & $\mathbf{F}$ & $\%$ \\
\hline 1 & Dasar & 25 & 62,5 \\
\hline 2 & Menengah & 11 & 27,5 \\
\hline \multirow[t]{2}{*}{3} & Tinggi & 4 & 10,0 \\
\hline & Jumlah & 40 & 100 \\
\hline No. & Pekerjaan & $\mathbf{F}$ & $\%$ \\
\hline 1 & IRT & 17 & 42,5 \\
\hline 2 & Pensiunan & 2 & 5,0 \\
\hline 3 & Petani & 12 & 30,0 \\
\hline 4 & PNS & 2 & 5,0 \\
\hline \multirow[t]{3}{*}{5} & Wirausaha & 7 & 17,5 \\
\hline & Jumlah & 40 & 100 \\
\hline & $\begin{array}{c}\text { Kategori } \\
\text { Hipertensi }\end{array}$ & $\mathbf{F}$ & $\%$ \\
\hline 1 & Pre-Hipertensi & 25 & 62,5 \\
\hline 2 & Stage 1 & 13 & 32,5 \\
\hline 3 & Stage 2 & 2 & 20,0 \\
\hline & Jumlah & 40 & 100,0 \\
\hline
\end{tabular}

Hasil penelitian data demografi frekuensi responden didapatkan bahwa perderita hipertensi yang terdapat di Gampong Meunasah Tambo mayoritas berusia antara 36-45 tahun dan 46-55 tahun yaitu masingmasing 15 orang $(37,5 \%)$, dengan jenis kelamin perempuan yaitu sebanyak 21 orang $(52,5 \%)$, berpendidikan Sedang yaitu sebanyak 25 orang $(62,5 \%)$ serta berprofesi sebagai IRT yaitu sebanyak 17 orang $(42,5 \%)$, serta mayoritas responden dengan derajat prehipertensi yaitu sebanyak 21 orang $(52,2 \%)$.

\section{Analisis Univariat}

\section{Dukungan Informasional}

Tabel 2 Dukungan Informasional Responden $(n=40)$

\begin{tabular}{cccc}
\hline No & Katagori & F & \% \\
\hline 1 & Baik & 26 & 65,5 \\
2 & Kurang baik & 14 & 35,5 \\
\hline & Jumlah & $\mathbf{4 0}$ & $\mathbf{1 0 0}$ \\
\hline
\end{tabular}

Mayoritas responden mendapatkan dukungan informasional yang baik yaitu sebanyak 26 orang $(65,5 \%)$, dibandingkan dengan yang kurang baik hanya 14 orang $(35,5 \%)$.
Dukungan Penghargaan

Tabel 3 Dukungan Penghargaan Responden $(\mathrm{n}=40)$

\begin{tabular}{cccc}
\hline No & Katagori & F & \% \\
\hline 1 & Baik & 23 & 57,5 \\
2 & Kurang baik & 17 & 42,5 \\
\hline & Jumlah & $\mathbf{4 0}$ & $\mathbf{1 0 0}$ \\
\hline
\end{tabular}

Mayoritas responden mendapatkan dukungan penghargaan yang baik yaitu sebanyak 23 orang $(57,5 \%)$, dibandingkan dengan yang kurang baik hanya 17 orang $(42,5 \%)$

Dukungan Instrumental

Tabel 4 Dukungan Instrumental Responden $(\mathrm{n}=40)$

\begin{tabular}{cccc}
\hline No & Katagori & F & \% \\
\hline 1 & Baik & 26 & 65,0 \\
2 & Kurang baik & 14 & 35,0 \\
\hline & Jumlah & $\mathbf{4 0}$ & $\mathbf{1 0 0}$ \\
\hline
\end{tabular}

Mayoritas responden mendapatkan dukungan instrumental yang baik yaitu sebanyak 26 orang $(65,0 \%)$, dibandingkan dengan yang kurang baik hanya 14 orang $(35,0 \%)$.

\section{Dukungan Emosional}

Tabel 5 Dukungan Emosional Responden $(\mathrm{n}=40)$

\begin{tabular}{cccc}
\hline No & Katagori & F & \% \\
\hline 1 & Baik & 26 & 65,0 \\
2 & Kurang baik & 14 & 35,0 \\
\hline & Jumlah & $\mathbf{4 0}$ & $\mathbf{1 0 0}$ \\
\hline
\end{tabular}

Mayoritas responden mendapatkan dukungan emosional yang baik yaitu sebanyak 26 orang $(65,0 \%)$, dibandingkan dengan yang kurang baik hanya 14 orang $(35,0 \%)$.

\section{Dukungan Keluarga}

Tabel 6 Dukungan Keluarga Responden $(\mathrm{n}=40)$

\begin{tabular}{cccc}
\hline No & Katagori & F & \% \\
\hline 1 & Baik & 21 & 52,5 \\
2 & Kurang baik & 19 & 47,5 \\
\hline & Jumlah & $\mathbf{4 0}$ & $\mathbf{1 0 0}$ \\
\hline
\end{tabular}

Mayoritas responden mendapatkan dukungan keluarga yang baik yaitu sebanyak 
21 orang $(52,5 \%)$, dibandingkan dengan yang kurang baik hanya 19 orang $(47,5 \%)$.

\begin{tabular}{|c|c|c|c|c|c|c|c|c|c|}
\hline \multicolumn{10}{|c|}{ Analisis Bivariat } \\
\hline \multirow{2}{*}{\multicolumn{7}{|c|}{$\begin{array}{l}\text { Hubungan Dukungan } \\
\text { Dengan Derajat Hipertensi }\end{array}$}} & \multirow{2}{*}{\multicolumn{3}{|c|}{ Informasional }} \\
\hline & & & & & & & & & \\
\hline Tabel 7 & & $\begin{array}{l}\text { luku } \\
\text { liper }\end{array}$ & $\begin{array}{l}\text { Ingan } \\
\text { rtensi }\end{array}$ & & Info & rma & asion & 1-De & rajat \\
\hline \multirow{2}{*}{$\begin{array}{l}\text { Dukungan } \\
\text { Informasio } \\
\text { nal }\end{array}$} & \multicolumn{6}{|c|}{ Derajat Hipertensi } & \multirow[b]{2}{*}{ Total } & \multirow[b]{2}{*}{$\%$} & \\
\hline & Pre & $\%$ & Stage 1 & $\%$ & Stage 2 & $\%$ & & & \\
\hline Baik & 19 & 73,1 & 5 & 19,2 & 2 & 7,7 & 26 & 65,0 & 0.001 \\
\hline Kurang baik & 2 & 14,3 & 6 & 42,9 & 6 & 42,9 & 14 & 35,0 & \\
\hline Total & 21 & 52,5 & 11 & 27,5 & 8 & 20,0 & 40 & 100 & \\
\hline
\end{tabular}

Pada dukungan informasional baik mayoritas mengalami pre hipertensi $(73,1 \%)$ dibandingkan dengan responden pada dukungan informasional kurang baik $(14,3 \%)$. Sebaliknya responden pada dukungan informasional kurang baik mayoritas mengalami hipertensi stage $1 \& 2$ (42,9\%) dibandingkan dengan responden pada dukungan informasional baik $(7,7 \%)$.

Hasil uji statistik menunjukkan ada hubungan antara dukungan infomasional dengan derajat hipertensi dengan nilai $p$ value sebesar $0,001<0,05$, yang artinya terdapat hubungan yang bermakna antara dukungan informasional dengan derajat hipertensi pada pasien hipertensi di Gampong Meunasah Tambo Kecamatan Peudada Kabupaten Bireuen Tahun 2020.

\section{Hubungan Dukungan Penghargaan Dengan derajat Hipertensi}

Tabel 8 Dukungan Penghargaan-Derajat Hipertensi

\begin{tabular}{|c|c|c|c|c|c|c|c|c|c|}
\hline \multirow{2}{*}{$\begin{array}{l}\text { Dukungan } \\
\text { Pengharga } \\
\text { an }\end{array}$} & \multicolumn{6}{|c|}{ Derajat Hipertensi } & \multirow[b]{2}{*}{$\mathbf{T}$} & \multirow[b]{2}{*}{$\%$} & \multirow[b]{2}{*}{$P$} \\
\hline & Pre & $\%$ & Stage 1 & $\%$ & Stage 2 & $\%$ & & & \\
\hline Baik & 17 & 73,9 & 2 & 8,7 & 4 & 17,4 & 23 & 57,5 & \\
\hline Kurang baik & 4 & 23,5 & 9 & 52,9 & 4 & 23,5 & 17 & $\overline{42,5}$ & 0.003 \\
\hline Total & 21 & 52,5 & 11 & 27,5 & 8 & 20,0 & 40 & 100 & \\
\hline
\end{tabular}
mayoritas mengalami pre hipertensi $(73,9 \%)$ dibandingkan dengan responden pada dukungan penghargaan kurang baik $(23,5 \%)$. Sebaliknya responden pada dukungan penghargaan kurang baik mayoritas mengalami hipertensi stage $1(52,9 \%)$ dibandingkan dengan responden pada dukungan penghargaan baik $(8,7 \%)$.

Hasil uji statistik menunjukkan ada hubungan antara dukungan penghargaan dengan derajat hipertensi dengan nilai $p$ value sebesar $0,003<0,05$, yang artinya terdapat hubungan yang bermakna antara dukungan penghargaan dengan derajat hipertensi pada pasien hipertensi di Gampong Meunasah Tambo Kecamatan Peudada Kabupaten Bireuen Tahun 2020.

\section{Hubungan Dukungan Instrumental Dengan derajat Hipertensi}

Tabel 9 Crosstab Dukungan InstrumentalDerajat Hipertensi

\begin{tabular}{|c|c|c|c|c|c|c|c|c|c|}
\hline \multirow{2}{*}{$\begin{array}{l}\text { Dukungan } \\
\text { Instrumental }\end{array}$} & \multicolumn{6}{|c|}{ Derajat Hipertensi } & \multirow[b]{2}{*}{$\mathbf{T}$} & \multirow[b]{2}{*}{$\%$} & \multirow[b]{2}{*}{$P$} \\
\hline & Pre & $\%$ & Stage 1 & $\%$ & Stage 2 & $\%$ & & & \\
\hline Baik & 19 & 73,1 & 4 & 15,4 & 3 & 11,5 & 26 & 65 & \\
\hline Kurang baik & 2 & 14,3 & 7 & 63,6 & 5 & 62,5 & 14 & 35 & 0.002 \\
\hline Total & 21 & 52,5 & 11 & 27,5 & 8 & \begin{tabular}{ll|}
20,0 \\
\end{tabular} & 40 & 100 & \\
\hline
\end{tabular}
mayoritas mengalami pre hipertensi $(73,1 \%)$ dibandingkan dengan responden pada dukungan instrumental kurang baik $(14,3 \%)$. Sebaliknya responden pada dukungan instrumental kurang baik mayoritas mengalami hipertensi stage $1(63,6 \%)$ dibandingkan dengan responden pada dukungan instrumental baik $(15,4 \%)$.

Hasil uji statistik menunjukkan ada hubungan antara dukungan instrumental dengan derajat hipertensi dengan nilai $p$ value sebesar $0,002<0,05$, yang artinya terdapat hubungan yang bermakna antara dukungan instrumental dengan derajat hipertensi pada pasien hipertensi di Gampong Meunasah Tambo Kecamatan Peudada Kabupaten Bireuen Tahun 2020.

\section{Hubungan Dukungan Emosional Dengan Derajat Hipertensi}

Tabel 10 Dukungan Emosional-Derajat Hipertensi

\begin{tabular}{|c|c|c|c|c|c|c|c|c|c|}
\hline \multirow{2}{*}{$\begin{array}{l}\text { Dukungan } \\
\text { Emosional }\end{array}$} & \multicolumn{6}{|c|}{ Derajat Hipertensi } & \multirow[b]{2}{*}{$\mathbf{T}$} & \multirow[b]{2}{*}{$\%$} & \multirow[b]{2}{*}{$P$} \\
\hline & Pre & $\%$ & Stage 1 & $\%$ & Stage 2 & $\%$ & & & \\
\hline Baik & 18 & 69,2 & 4 & 15,4 & 4 & 15,4 & 26 & 65 & 0.013 \\
\hline $\begin{array}{c}\text { Kurang } \\
\text { baik }\end{array}$ & 3 & 21,4 & 7 & 50,0 & 4 & 28,6 & 14 & 35 & \\
\hline Total & 21 & 52,5 & 11 & 27,5 & 8 & 20,0 & 40 & 100 & \\
\hline
\end{tabular}
mayoritas mengalami pre hipertensi $(69,2 \%)$ dibandingkan dengan responden pada dukungan emosional kurang baik $(21,4 \%)$. Sebaliknya responden pada dukungan emosional kurang baik mayoritas mengalami hipertensi stage $1 \quad(50,0 \%)$ dibandingkan dengan responden pada dukungan emosional baik $(15,4 \%)$. 
Hasil uji statistik menunjukkan ada hubungan antara dukungan penghargaan dengan derajat hipertensi dengan nilai $p$ value sebesar $0,013<0,05$, yang artinya terdapat hubungan yang bermakna antara dukungan emosional dengan derajat hipertensi pada pasien hipertensi di Gampong Meunasah Tambo Kecamatan Peudada Kabupaten Bireuen Tahun 2020.

\section{Hubungan Dukungan Keluarga Dengan Derajat Hipertensi}

Tabel 11 Dukungan Keluarga-Derajat Hipertensi

\begin{tabular}{|c|c|c|c|c|c|c|c|c|c|}
\hline \multirow{2}{*}{$\begin{array}{c}\text { Dukungan } \\
\text { Keluarga }\end{array}$} & \multicolumn{6}{|c|}{ Derajat Hipertensi } & \multirow[b]{2}{*}{$\mathbf{T}$} & \multirow{2}{*}{$\%$} & \multirow{2}{*}{$P$} \\
\hline & Pre & $\%$ & Stage 1 & $\%$ & Stage 2 & $\%$ & & & \\
\hline Baik & 17 & 81,0 & 1 & 4,8 & 3 & 14,3 & 21 & 52,50 & 0.000 \\
\hline Kurang baik & 4 & 21,1 & 10 & 52,6 & 5 & 26,3 & 19 & 47,5 & \\
\hline Total & 21 & 52,5 & 11 & 27,5 & 8 & 20,0 & 40 & 100 & \\
\hline
\end{tabular}

Pada dukungan keluarga baik mayoritas mengalami pre hipertensi $(81,0 \%)$ dibandingkan dengan responden pada dukungan keluarga kurang baik $(21,1 \%)$. Sebaliknya responden pada dukungan keluarga kurang baik mayoritas mengalami hipertensi stage $1 \quad(52,5 \%)$ dibandingkan dengan responden pada dukungan emosional baik $(4,8 \%)$.

Hasil uji statistik menunjukkan ada hubungan antara dukungan keluarga dengan derajat hipertensi dengan nilai $p$ value sebesar $0,000<0,05$, yang artinya terdapat hubungan yang bermakna antara dukungan keluarga dengan derajat hipertensi pada pasien hipertensi di Gampong Meunasah Tambo Kecamatan Peudada Kabupaten Bireuen Tahun 2020.

\section{PEMBAHASAN}

\section{Dukungan Keluarga Pada Pasien Hipertensi}

Berdasarkan hasil penelitian yang dilakukan di Gampong Meunasah Tambo Kecamatan Peudada Kabupaten Bireuen didapatkan bahwa sebagian besar responden memiliki dukungan informasional yang baik $(65,5 \%)$ dibandingkan dengan yang kurang baik (35,5\%), memiliki dukungan penghargaan yang baik (57,5\%), dibandingkan dengan yang kurang baik $(42,5 \%)$, memiliki dukungan instrumental yang baik $(65,0 \%)$, dibandingkan dengan yang kurang baik $(35,0 \%)$ dan memiliki dukungan emosional yang baik $(65,0 \%)$, dibandingkan dengan yang kurang baik $(35,0 \%)$. Hal ini menunjukkan bahwa mayoritas keluarga telah menerapkan fungsi keluarga dengan baik khususnya dalam menerapkan dukungan informasional yang optimal bagi anggota keluarga yang membutuhkan perhatian akan kesehatannya.

Keluarga merupakan sekumpulan orang yang saling berinteraksi didalam sebuah sistem sosial yang kecil yang mempunyai ikatan dan keterkaitan satu sama lain dalam menciptakan dan mempertahankan budaya yang umum, meningkatkan perkembangan dan kesehatan fisik, mental, emosional dan sosial. Keluarga adalah unit terkecil dari masyarakat yang terdiri dari kepala keluarga dan beberapa orang yang berkumpul dan tinggal disuatu tempat di bawah satu atap dalan keadaan saling ketergantungan (Syamsul, 2016).

Keluarga berperan sangat penting dalam mengupayakan kesehatan dalam keluarga. Adanya masalah kesehatan pada salah satu anggota keluarga lainnya.Setiap individu dalam keluarga memerlukan dukungan dalam setiap siklus kehidupan. Dukungan keluarga adalah sebuah proses yang terjadi sepanjang masa kehidupan, sifat dan jenis dukungan berbeda dalam berbagaitahap siklus kehidupan. Dukungan keluarga dapat berupa dukungan sosial internal, seperti dukungan dari suami, istri atau dukungan dari saudara kandung dan dapat juga berupa dukungan keluarga eksternal bagi keluarga inti. Secara spesifik dengan adanya dukungan keluarga yang adekuat maka angka mortalitas pada pasien hipertensi dapat menurun (Fajriyah $e t$ al., 2016).

Hal ini sejalan dengan penelitian Elly \& Rahayu (2020) tentang hubungan dukungan keluarga dengan perilaku perawatan hipertensi yang dilakukan oleh keluarga di rumah berhasil menyimpulkan bahwa ada hubungan yang signifikan antara hubungan dukumgan keluarga dengan perilaku perawatan hipertensi yang dilakukan oleh keluarga di rumah $(\mathrm{P}=$ 0,003 ).

Berdasarkan hasil penelitian dan teori tersebut dapat dijelaskan bahwa faktor dukungan keluarga (informasional, penghargaan, instrumental dan emosional) 
sangat dibutuhkan untuk menunjang kesehatan seluruh anggota keluarganya, dalam hal ini dengan baiknya dukungan keluarga, maka manajemen kesehatan keluarga dengan hipertensimampu menjaga supaya derajat hipertensi yang diderita oleh pasien tidak bertambah parah serta akan tetap terjaga lingkungan sosial keluarga yang hangat dan menyehatkan.

Dengan demikan, dapat disimpulkan bahwa dukungan keluarga pada pasien hipertensi di Gampong Meunasah Tambo Kecamatan Peudada, Kabupaten Bireuen tahun 2020 berada pada kategori baik. Dari hasil tersebut juga dapat dilihat bahwa peranan keluarga dalam memberikan stimulus pada setiap anggota keluarga sangat diperlukan.

\section{Derajat Hipertensi Pada Pasien Hipertensi}

Berdasarkan hasil penelitian yang dilakukan di Gampong Meunasah Tambo Kecamatan Peudada Kabupaten Bireuen didapatkan bahwa sebagian besar responden mengalami pre hipertensi $(52,5 \%)$, dibandingkan denganstage $1 \quad(27,5 \%)$ sertastage $2(20 \%)$. Hal ini menunjukkan bahwa mayoritas responden mengalami hipertensi derajat awal (pre-hipertensi).

Menurut Americant Society of Hypertention (ASH), hipertensi merupakan suatu kumpulan gejala kardiovaskuler progresif yang terjadi akibat dari kondisi lain yang kompleks dan saling berhubungan. Hipertensi terjadi di saat tekanan darah sistolik lebih atau sama dengan $140 \mathrm{mmHg}$ dan tekanan darah diastolik lebih atau sama dengan $90 \mathrm{mmHg}$ atau mengkonsumsi obat anti hipertensi (Nuraini, 2015).Sejalan dengan Joint National Commite (JNC) yang menyampaikan bahwa hipertensi adalah tekanan darah yang lebih dari 140/90 mmHg (Kemenkes, 2014).

Hipertensi merupakan tanda klinis ketidakseimbangan hemodinamik suatu sistem kardiovaskular, di mana penyebab terjadinya disebabkan oleh beberapa faktor/ multifaktor sehingga tidak bisa terdiagnosis dengan hanya satu faktor tunggal (Setiati, 2015).

Pasien dengan derajat hipertensi normal tidak menutup kemungkinan akan tetap normal saat diperiksa kedepan lagi tanpa ada manajemen kesehatan keluarga dan individu yang baik. Untuk itudiperlukan manajemen kesehatan yang menyeluruh baik internal maupun eksternal agar tekanan darah tetap dalam keadaan terkontrol (Fauzi, 2014).

Hasil ini sesuai dengan penelitian dari Bisnu, Bily dan Mulyadi (2017) tentang hubungan dukungan keluarga dengan derajat hipertensi pada pasien hipertensi di Puskesmas Ranomuut Kota Manado dengan menggunakan tiga kategori hipertensi (pre hipertensi, hipertensi dan hipertensi stage 1) berhasil menyimpulkan bahwa sebagian besar responden mengalami pre hipertensi $(54,4 \%)$, dan sisanya hipertensi $(45,6 \%)$.

Berdasarkan hasil penelitian dan teori tersebut dapat dijelaskan bahwa hipertensi merupakan salah satu masalah kesehatan yang serius bukan hanya dari gejala-gejala yang akan terjadi tetapi resiko komplikasi yang tinggi juga harus terus dihindari, salah satu cara yang bisa dilakukan adalah dengan selalu rutin mengukur tekanan darah sehingga responden bisa tahu derajat hipertensi yang di alaminya sudah sejauh mana, sehingga langkah-langkah pengobatan yang ditempuh pun akan tepat.

Dengan demikan, dapat disimpulkan bahwa derajat hipertensi pada pasien hipertensi di Gampong Meunasah Tambo Kecamatan Peudada, Kabupaten Bireuen tahun 2020 mayoritas masih berada pada kategori pre hipertensi. Hal ini menggambarkan bahwa manajemen kesehatan keluarga khususnya dengan hipertensi sudah berjalan dengan baik.

\section{Hubungan Dukungan Informasional Dengan Derajat Hipertensi}

Berdasarkan hasil uji statistik cross tabulating dukungan informasional dengan derajat hipertensi, didapatkan bahwa ada hubungan yang signifikan antara dukungan informasional dengan derajat hipertensi pada pasien hipertensi di Gampong Meunasah Tambo Kecamatan Peudada Kabupaten Bireuen Tahun 2020 dengan $\mathrm{p}$ value $=0,001$ yang menunjukkan nilai kurang dari $\alpha=0,05$.

Dukungan informasional keluarga berfungsi sebagai sebuah kolektor dan disseminator (penyebar) informasi tentang dunia. Dukungan informasi terjadi dan diberikan oleh keluarga dalam bentuk nasehat, saran dan diskusi tentang bagaimana cara 
mengatasi atau memecahkan masalah yang ada (Sarafino, 2011). Hal ini juga sejalan dengan teori Friedman (2013) yang menyatakan bahwa dukungan informasional di dalam sebuah keluarga berfungsi sebagai tempat pengumpul dan penyebar informasi kepada seluruh anggota keluarganya. Menjelaskan tentang pemberian saran dan sugesti, informasi yang dapat digunakan untuk mengungkapkan tentang suatu masalah. Manfaat dari dukungan ini adalah dapat menekan munculnya suatu stressor karena informasi yang diberikan dapat menyumbangkan aksi sugesti yang khusus pada individu. Aspek-aspek dalam dukungan ini adalah nasehat, usulan, saran, petunjuk dan pemberian informasi.

Dari penelitian yang dilakukan oleh Listy (2017) tentang hubungan pengetahuan keluarga tentang hipertensi dengan dukungan keluarga dalam proses penyembuhan hipertensi pada lansia didapatkan bahwa ada hubungan yang signifikan antara pengetahuan keluarga tentang hipertensi dengan dukungan keluarga dalam proses penyembuhan hipertensi pada lansia $(p=0,000 \leq 0,05)$. sehingga peneliti berasumsi bahwa adanya dukungan informasional keluarga yang baikmembuat responden dengan masalah tekanan darah tinggi mampu menerapkan setiap intervensi yang tepat untuk mengontrol tekanan darahnya supaya derajat hipertensinya terkontrol.

Berdasarkan hasil penelitian dan teori di atas, peneliti berasumsi bahwa dukungan informasional menjadi salah satu wadah informasi yang berguna bagi kelangsungan hidup sehari-hari dalam keluarga berisi nasehat, usulan, saran, bimbingan, pengingat dan sebagainya. Sehingga dengan adanya informasi-informasi yang bermanfaat ini nantinya akan membimbing setiap anggota keluarga dalam bersikap dan berperilaku. Dalam hal ini jika ada yang mengalami hipertensi maka anggota keluarga tersebut akan mampu menentukan sikap dan tindakannya untuk membuat kondisi penyakitnya menjadi lebih baik lagi.

Peneliti berkesimpulan bahwa ada hubungan yang signifikan antara dukungan informasional dengan derajat hipertensi pada pasien hipertensi di Gampong Meunasah
Tambo Kecamatan Peudada Kabupaten Bireuen Tahun 2020 ( $\mathrm{p}$ value $=0,001)$.

\section{Hubungan Dukungan Penghargaan Dengan Derajat Hipertensi}

Berdasarkan hasil uji statistik cross tabulating dukungan penghargaan dengan derajat hipertensi, didapatkan bahwa ada hubungan yang signifikan antara dukungan penghargaan dengan derajat hipertensi pada pasien hipertensi di Desa Meunasah Tambo Kecamatan Peudada Kabupaten Bireuen Tahun 2020 dengan $\mathrm{p}$ value $=0,003$ yang menunjukkan nilai kurang dari $\alpha=0,05$.

Keluarga bertindak sebagai sistem pembimbing umpan balik, membimbing dan memerantai pemecahan masalah dan merupakan sumber validator identitas anggota. Dukungan penghargaan terjadi melalui ekspresi penghargaan yang positif melibatkan pernyataan setuju dan penilaian positif terhadap ide-ide, perasaan dan performa orang lain yang berbanding positif antara individu dengan orang lain (Sarafino, 2011).

Dukungan penghargaan meliputi pertolongan pada individu untuk memahami kejadian hipertensi dengan baik dan juga sumber hipertensi dan strategi yang dapat digunakan dalam menghadapi hipertensi. Dukungan ini juga merupakan dukungan yang terjadi bila ada ekspresi penilaian yang positif terhadap individu. Individu mempunyai seseorang yang dapat diajak bicara tentang masalah mereka, terjadi melalui ekspresi pengaharapan positif individu kepada individu lain, penyemangat, persetujuan terhadap ideide atau perasaan seseorang dan perbandingan positif seseorang dengan orang lain, misalnya orang yang kurang mampu. Dukungan keluarga dapat membantu meningkatkan strategi individu dengan strategi-strategi alternatif berdasarkan pengalaman yang berfokus pada aspek-aspek yang positif (Friedman, 2013).

Dari penelitian Wahid \& Farhan (2020) tentang hubungan dukungan keluarga pada pasien dengan tekanan darah tinggi dalam pengendalian hipertensi didapatkan bahwa ada hubungan yang signifikan antara dukungan keluarga pada pasien dengan tekanan darah tinggi dalam pengendalian hipertensi $(\mathrm{p}=$ 0.000). Peneliti berasumsi melalui dukungan 
penghargaan keluarga yang baik dari setiap anggota keluarga juga akan membuat penderita hipertensi merasa terdorong untuk terus berusaha menjalani proses pengobatan sebaik mungkin.

Berdasarkan hasil penelitian dan teori di atas, peneliti berasumsi bahwa melalui wujud dukungan penghargaan yang dihadirkan didalam lingkungan keluarga akan memberi suatu arahan sekaligus suatu rasa antusiasme dalam pemecahanan setiap masalah baik itu masalah kesehatan maupun masalah sosial lainnya. Dari dukungan penghargaan positif yang didapatkan, anggota keluarga akan menuntun pada perilaku dan sikap yang tepat untuk setiap masalah yang dihadapi seharihari, dalam hal ini dengan dukungan penghargaan positif yang didapatkan responden akan semangat dan yakin dalam menjaga pola hidup serta menjalani pengobatan untuk mengurangi gejala hipertensinya.

Peneliti berkesimpulan bahwa ada hubungan yang signifikan antara dukungan penghargaan denganderajat hipertensi pada pasien hipertensi di Gampong Meunasah Tambo Kecamatan Peudada Kabupaten Bireuen Tahun 2020 ( $p$ value $=0,003$ )

\section{Hubungan Dukungan Instrumental Dengan Derajat Hipertensi}

Berdasarkan hasil uji statistik cross tabulating dukungan instrumental dengan derajat hipertensi, didapatkan bahwa ada hubungan yang signifikan antara dukungan instrumental dengan derajat hipertensi pada pasien hipertensi di Gampong Meunasah Tambo Kecamatan Peudada Kabupaten Bireuen Tahun 2020 dengan $\mathrm{p}$ value $=0,002$ yang menunjukkan nilai kurang dari $\alpha=0,05$.

Keluarga mampu menjadi sebuah sumber pertolongan praktis dan konkrit salah satunya melalui dukungan instrumental, yaitu dukungan yang diberikan oleh keluarga secara langsung yang meliputi bantuan material seperti memberikan tempat tinggal, meminjamkan atau memberikan uang dan bantuan dalam kehidupan sehari-hari (Sarafino, 2011).

Dalam teorinya Friedman (2013) juga menyatakan bahwa dukungan instrumental meliputi penyediaan dukungan jasmaniah seperti pelayanan, bantuan finansial dan material berupa bantuan nyata (instrumental support material support), suatu kondisi dimana benda atau jasa akan membantu memecahkan masalah praktis, termasuk di dalamnya bantuan langsung, seperti saat seseorang memberi atau meminjamkan uang, membantu pekerjaan sehari-hari, menyampaikan pesan, menyediakan transportasi, menjaga dan merawat saat sakit ataupun mengalami depresi yang dapat membantu memecahkan masalah. Dukungan nyata paling efektif bila dihargai oleh individu dan mengurangi depresi individu. Pada dukungan nyata keluarga sebagai sumber untuk mencapai tujuan praktis dan tujuan nyata.

Dari hasil penelitian Islamiati (2017) tentang hubungan dukungan keluarga dengan kemandirian lansia dalam pemenuhan aktifitas sehari-hari di Desa Ngiliran Kabupaten Magetan didapatkan bahwa ada hubungan yang signifikan antara dukungan keluarga dengan kemandirian lansia $(\mathrm{p}=0,000)$, dari hasil study ini peneliti berasumsi melalui dukungan instrumental keluarga akan mampu memfasilitasi seluruh anggota keluarganya terutama yang sakit supaya dapat tercapai dengan maksimal usaha yang ditempuh untuk mengembalikan kesejahteraan jasmani, begitu juga keluarga dengan masalah hipertensi akan mampu menjaga derajat hipertensi tetap stabil bahkan berkurang.

Berdasarkan hasil penelitian dan teori di atas, peneliti berasumsi bahwa melalui wujud dukungan instrumental yang dihadirkan seperti fasilitas-fasilitas, material atau finansial kepada setiap anggota keluarga sesuai dengan kebutuhannya masing-masing maka hal tersebut akan sangat membantu dalam pencapaian kesehjahteraan jasmani anggota keluarga, sehingga responden dengan hipertensi yang memperoleh dukungan instrumental yang baik dari keluargaakan membuat responden mampu merencanakan intervensi yang tepat dalam mengurangi derajat hipertensinya.

Peneliti berkesimpulan bahwa ada hubungan yang signifikan antara dukungan instrumental dengan derajat hipertensi pada pasien hipertensi di Gampong Meunasah Tambo Kecamatan Peudada Kabupaten Bireuen Tahun 2020 ( $\mathrm{p}$ value $=0,003$ ). 
Hubungan Dukungan Emosional Dengan Derajat Hipertensi

Berdasarkan hasil uji statistik cross tabulating dukungan emosional dengan derajat hipertensi, didapatkan bahwa ada hubungan yang signifikan antara dukungan emosional dengan derajat hipertensi pada pasien hipertensi di Gampong Meunasah Tambo Kecamatan Peudada Kabupaten Bireuen Tahun 2020 dengan $\mathrm{p}$ value $=0,013$ yang menunjukkan nilai kurang dari $\alpha=0,05$.

Dukungan emosional melibatkan ekspresi empati, perhatian, pemberian semangat, kehangatan pribadi, cinta, atau bantuan emosional. Dengan semua tingkah laku yang mendorong perasaan nyaman dan mengarahkan individu untuk percaya bahwa ia dipuji, dihormati, dan dicintai, dan bahwa orang lain bersedia untuk memberikan perhatian (Sarafino, 2011).

Selama mengalami hipertensi, individu sering menderita secara emosional, sedih, cemas dan kehilangan harga diri. Dukungan emosional memberikan individu perasaan nyaman, merasa dicintai saat mengalami depresi, bantuan dalam bentuk semangat, empati, rasa percaya, perhatian sehingga individu yang menerimanya merasa berharga. Pada dukungan emosional ini keluarga menyediakan tempat istirahat dan memberikan semangat (Friedman, 2013).

Dari penelitian Utami \& Salamah (2016) tentang hubungan dukungan sosial keluarga dengan kepatuhan berobat penderita hipertensi didapatkan bahwa ada hubungan yang signifikan antara dukungan sosial keluarga dengan kepatuhan berobat penderita hipertensi $(\mathrm{p}=0,000<0,05)$ artinya semakin tinggi dukungan yang diberikan keluarga terhadap penderita hipertensi maka semakin tinggi pula kepatuhan berobat penderita hipertensi. Dari penelitian ini peneliti berasumsi bahwa melalui hubungan emosional yang baik antar anggota keluarga menjadi salah satu faktor yang menguatkan mental setiap anggota keluarga terutama anggota keluarga dalam keadaan sakit yang sangat membutuhkan dukungan dari anggota keluarga lain.

Berdasarkan hasil penelitian dan teori di atas, peneliti berasumsi bahwa Dukungan emosional diibaratkan sebagai pelabuhan istirahat dan pemulihan serta membantu penguasaan emosional, sehingga responden tidak merasa depresi dengan hipetensi yang dideritanya karena dengan sugesti positif dari keluarga responden dapat merasa bahwa dia akan baik-baik saja selama berada bersama keluarga.

Peneliti berkesimpulan bahwa ada hubungan yang signifikan antara dukungan emosional dengan derajat hipertensi pada pasien hipertensi di Gampong Meunasah Tambo Kecamatan Peudada Kabupaten Bireuen Tahun 2020 ( $\mathrm{p}$ value $=0,013$ ).

\section{Hubungan Dukungan Keluarga Dengan Derajat Hipertensi}

Berdasarkan hasil uji statistik cross tabulating dukungan keluarga dengan derajat hipertensi, didapatkan bahwa ada hubungan yang signifikan antara dukungan keluarga dengan derajat hipertensi pada pasien hipertensi di Gampong Meunasah Tambo Kecamatan Peudada Kabupaten Bireuen Tahun 2020 dengan $\mathrm{p}$ value $=0,000$ yang menunjukkan nilai kurang dari $\alpha=0,05$. Hasil Penelitian ini sejalan dengan penelitian Bisnu, Billy dan Mulyadi (2017) tentang hubungan dukungan keluarga dengan derajat hipertensi pada pasien hipertensi di puskesmas ranomuut kota manado yang juga mendapatkan bahwa ada hubungan yang signifikan antara dukungan keluarga dengan derajat hipertensi $(\mathrm{P}=0,000)$ semakin baik dukungan keluarga maka akan semakin baik pula tingkat derajat hipertensinya.

Keluarga merupakan sekumpulan orang yang bersama-sama bersatu dengan melakukan pendekatan emosional dan mengidentifikasi dirinya sebagian dari keluarga. Keluarga merupakan sistem dasar dimana perilaku kesehatan seseorang dengan perawatan kesehatan sudah diatur, dilakukan serta diamankan oleh keluarga sebagai bentuk perawatan yang secara preventif (Friedman, 2014).

Dukungan sosial keluarga mengacu kepada dukungan-dukungan sosial yang dipandang oleh anggota keluarga sebagai sesuatu yang dapat diakses atau diadakan untuk keluarga yang selalu siap memberikan pertolongan dan bantuan jika diperlukan (Erdiana, 2015). Friedman (2014) dalam teorinya juga menjelaskan bahwa dukungan keluarga meliputi sikap, tindakan penerimaan keluarga terhadap anggota keluarganya, 
dukungan informasional, dukungan penilaian, dukungan instrumental dan dukungan emosional. Jadi dukungan keluarga adalah suatu bentuk hubungan interpersonal yang meliputi sikap, tindakan dan penerimaan terhadap anggota keluarga, sehingga anggota keluarga merasa ada yang memperhatikan.

Dukungan sosial keluarga mengacu kepada dukungan-dukungan sosial yang dipandang oleh anggota keluarga sebagai sesuatu yang dapat diakses atau diadakan untuk keluarga yang selalu siap memberikan pertolongan dan bantuan jika diperlukan (Erdiana, 2015).

Sangatlah luas diterima bahwa orang yang berada dalam lingkungan sosial yang suportif umumnya memiliki kondisi yang lebih baik dibandingkan rekannya yang tanpa keuntungan ini. Lebih khususnya, karena dukungan sosial dapat dianggap mengurangi atau menyangga efek serta meningkatkan kesehatan mental individu atau keluarga secara langsung, dukungan sosial adalah strategi penting yang harus ada dalam masa stress bagi keluarga (Friedman, 2010).

Hasil penelitian ini juga sejalan dengan penilitian yang dilakukan Perdana (2017) yang berjudul "hubungan dukungan keluarga dengan kepatuhan diit hipertensi pada lansia di Dusun Depok Ambar Ketawang Gamping Sleman Yogyakarta". Hasil penilitian ini menunjukan bahwa ada hubungan yang signifikan antara dukungan keluarga dengan diit pada pasien hipertensi dengan nilai $\mathrm{p}=0,001$.

Penelitian yang dilakukan oleh Annafiah (2018) tentang hubungan dukungan keluarga dengan kepatuhan kontrol pada lansia hipertensi di Puskesmas Kasihan II Bantul mendapatkan bahwa ada hubungan yang signifikan antara dukungan keluarga dengan kepatuhan kontrol pada lansia hipertensi $(\rho=0,000)$. Hal ini peneliti berasumsi bahwa dengan adanya dukungan keluarga yang baik maka pasien akan lebih peduli akan pentingnya mengontrol tekanan darah secara ruti sehingga derajat hipertensinya juga akan terus membaik.

Berdasarkan hasil penelitian dan teori di atas, peneliti berasumsi bahwa dalam sebuah keluarga konektifitas antar individu didalamnya harus berjalan dengan baik agar sistem keluarga dapat terbangun yang saling keterkaitan dalam hal fisik maupun jiwa, sehingga disaat sistem keluarga sudah berfungsi dengan benar jika ada salah satu individu yang sedang mengalami masalah kesehatan maka anggota keluarga yang lain akan mengirimkan dukungan-dukungan keluarga untuk menguatkan dan membimbing supaya anggota keluarga semua mencapai kesejahteraan bersama didalam berkeluarga.

Peneliti berkesimpulan bahwa ada hubungan yang signifikan antara dukungan keluarga dengan derajat hipertensi pada pasien hipertensi di Gampong Meunasah Tambo Kecamatan Peudada Kabupaten Bireuen Tahun 2020 ( $p$ value $=0,000$ ).

\section{KESIMPULAN DAN SARAN \\ Kesimpulan}

a. Mayoritas responden mendapatkan dukungan informasional yang baik $(65,5 \%)$, dukungan penghargaan yang baik $(57,5 \%)$, dukungan instrumental yang baik $(65,0 \%)$, dukungan emosional yang baik $(65,0 \%)$ serta dukungan keluarga secara keseluruhan yang baik pula $(52,5 \%)$.

b. Mayoritas responden memiliki derajat pre hipertensi (62,5\%), dibandingkan dengan yang stage $1(32,5 \%)$ dan stage $2(5 \%)$.

c. Bahwa ada hubungan yang bermakna antara dukungan informasional dengan derajat hipertensipada pasien hipertensi di Gampong Meunasah Tambo Kecamatan Peudada Kabupaten Bireuen Tahun 2020 $(P=0,001)$.

d. Bahwa ada hubungan yang bermakna antara dukungan penghargaan $(P=$ 0,003), dukungan instrumental $(P=$ $0,002)$ dan dukungan emosional $(P=$ 0,013 ) dengan derajat hipertensi pada pasien hipertensi di Gampong Meunasah Tambo Kecamatan Peudada Kabupaten Bireuen Tahun 2020.

e. Bahwa ada hubungan yang bermakna antara dukungan keluarga dengan derajat hipertensi pada pasien hipertensi di Gampong Meunasah Tambo Kecamatan Peudada Kabupaten Bireuen Tahun 2020 $(P=0,000)$. Semakin baik dukungan keluarga maka akan semakin baik pula derajat hipertensi pada pasien hipertensi. 


\section{Saran}

a. Bagi Peneliti

Diharapkan dapat menambah pengetahuan dan wawasan peneliti dalam melakukan penelitian serta dapat dijadikan dasar dalam melakukan penelitian selanjutnya tentang faktor-faktor yang mempengaruhi derajat hipertensi.

b. Bagi responden

Diharapkan untuk senantiasa tetap terbina lingkungan sosial keluarga yang harmonis, menjalankan fungsi serta peran-peran keluarga seperti yang seharusnya agar tersalurkan dukungan-dukungan keluarga secara maksimal kepada seluruh anggota keluarga.

c. Bagi institusi pendidikan

Diharapkan dapat menjadi rujukan baru untuk menarik minat peneliti selanjutnya untuk kesempurnaan penelitian ini.

d. Bagi peneliti selanjutnya

Diharapkan supaya dapat membuat penelitian lebih lanjut tentang bentuk dukungan keluarga yang paling berpengaruh terhadap derajat hipertensi serta faktor lain dari keluarga yang berhubungan dengan derajat hipertensi.

\section{DAFTAR PUSTAKA}

Annafiah Nur. (2018). Hubungan Dukungan Keluarga Dengan Kepatuhan Kontrol Pada Lansia Hipertensi Di Puskesmas Kasihan II Bantul.Yogyakarta : Universitas Alma Ata.

Asfuah, S. (2012). Buku Saku Klinik Untuk Keperawatan dan Kebidanan. Yogyakarta :Nuha Medika.

Almina T, Zulhaida L, \& Syarifah.(2016). Pengaruh Pengetahuan, Sikap, Dan Dukungan Kelu

arga Terhadap Diet Hipertensi Di Desa Hulu Kecamatan Pancur Batu. Deli Serdang : Universitas Sumatera Utara.

Bisnu, I. (2017). Hubungan Dukungan Keluarga Dengan Derajat Hipertensi Pada Pasien Hipertensi Di Puskesmas Ranomuut. Manado: Universitas Sam Ratulangi.
Daziah, E, \& Sri Rahayu. (2020). Hubungan Dukungan Keluarga Dengan Perilaku Perawatan Hipertensi Yang Dilakukan Oleh Keluarga Di Rumah. Jakarta: Sekolah Tinggi Ilmu Kesehatan Jayakarta

Dinas Kesehatan Aceh. (2015). Rekapan Laporan Surveilans Terpadu Penyakit Berbasis Puskesmas.Aceh : Pemprov.

Dinas Kesehatan. (2018). Profil Kesehatan Bireuen. Bireuen: Pemkab.

Efendi \& Larasati. (2016). Dukungan Keluarga dalam Manajemen Penyakit Hipertensi. Universitas Lampung: Fakultas Kedokteran.

Erdiana, Y. (2015). Dukungan Keluarga Dalam kunjungan Lansia Di posyandu lansia Di Desa Karanglolor Kecamatan Sukerejo Kabupaten Ponorogo. Ponorogo : Program studi D III Keperawatan Falkultas Ilmu Kesehatan Universitas Muhammadiyah Ponorogo.

Flynn, S. (2013).'Facilitators and barriers to hypertension self-management in urban African Americans: perspectives of patients and family members',.NCBI Journal, vol. 07.

Fauzi, \& Isma. (2014). Buku Pintar Deteksi Dini Gejala, \& Pengobatan Asam Urat, Diabetes \& Hipertensi. Yogyakarta: Araska.

Friedman, L, M. (2010). Buku Ajar Keperawatan Keluarga : Riset, Teori dan Praktek (5th ed). Jakarta : EGC.

. (2013). Buku Ajar Keperawatan Keluarga :Riset, Teori dan Praktek. Jakarta : EGC.

(2014). Buku Ajar Keperawatan Keluarga Teori \& Praktik. Jakarta : EGC.

Fajriah, N, \&Abdullah.(2016). Dukungan Sosial pada Pasien Hipertensi. Jurnal Ilmiah Kesehatan. Vol IX: 1-7. 
Islamiati, D.N., (2017). Hubungan Dukungan Keluarga Dengan Kemandirian Lansia Dalam Pemenuhan Aktifitas SehariHari Di Desa Ngiliran Kabupaten Magetan. Madiun: STIKes Bhakti Husada Mulia.

Isra, M.Bisnu, Billy, \&Mulyadi. (2017). Hubungan Dukungan Keluarga Dengan Derajat Hipertensi Pada Pasien Hipertensi Di Puskesmas Ranomuut Kota Manado. Manado: Universitas Sam Ratulangi.

Jacub, G. (2017). Functional Sosial Support For Hypertensive Patients In Primary Care Setting. Polandia.

Kementrian Kesehatan RI. (2014). Profil Kesehatan Indonesia. Jakarta: Kemenkes RI. .(2019).Pusat Data dan Informasi Kesehatan Kementerian Indonesia. Jakarta : Infodatin.

Listy, W. (2017). Hubungan Pengetahuan Keluarga Tentang Hipertensi Dengan Dukungan Keluarga Dalam Proses Penyembuhan Hipertensi Pada Lansia Di Puskesmas Banjarejo Kota Madiun. Madiun : Stikes Bhakti Husada Mulia.

Nuraini, B. (2015). Risk Factors Of Hypertension Volume 4 Nomer 5. Faculty of Medicine, University of Lampung : C. Majority.

Perki. (2015). Pedoman Tatalaksana Hipertensi Pada Penyakit Kardiovaskuler Edisi Pertama. Jakarta : PERKI.

Perdana, M, A. (2017). Hubungan Dukungan Keluarga Dengan Kepatuhan Diit Hipertensi Pada Lansia Di Dusun Depok Ambar ketawang Gamping Sleman. Yogyakarta: Fakultas Ilmu Kesehatan Universitas 'Aisyiyah.

Riskesdas.(2018). Riset Kesehatan Dasar. Jakarta: Kemenkes.
Sarafino, Edward P., Timothy W. \& Smith. (2011). Health Psychology Biopsychosocial Interactions Seventh edition. United States of America.

Setiati S, Alwi I, Sudoyo AW, Stiyohadi B \& Syam AF. (2015). Buku ajar ilmu penyakit dalam jilid I. VI. Jakarta: InternaPublishing.

Utami, R H, \& Raudatussalamah.(2016). Hubungan Dukungan Sosial Keluarga Dengan Kepatuhan Berobat Penderita Hipertensi Di Puskesmas Tualang. Riau : Universitas Islam Negeri Sultan Syarif Kasim.

Wahid, T W, \& Farhan, A,N. (2020). Hubungan Dukungan Keluarga Pada Pasien Dengan Tekanan Darah Tinggi Dalam Pengendalian Hipertensi Di Wilayah Kerja Puskesmas Panjang Kota Bandar Lampung. Bandar Lampung :Universitas Malahayati.

WHO . (2015). Data Hipertensi Global. Asia Tenggara: WHO. 